Bangladesh J. Bot. 44(1): 37-43, 2015 (March)

\title{
COMPARATIVE ANATOMICAL STUDIES ON SOME SPECIES OF HYOSCYAMUS L. (SOLANACEAE) GROWING IN TURKEY
}

\author{
Fathih Satil, Mustafa Aslan ${ }^{1}$, Eyüp ErdoĞan*, \\ Ridvan Polat ${ }^{2}$ and Selami Selvi ${ }^{3}$ \\ Department of Biology, Faculty of Science \& Art, Ballkesir University, \\ Çă̆lş Campus, 10145 Balıkesir, Turkey
}

Key words: Comparative anatomy, Leaf, Stem, Hyoscyamus, Solanaceae

\begin{abstract}
A comparative study based on leaf and stem anatomical structure was made using light microscopy (LM) techniques on five species of Hyoscyamus L. (Solanaceae) in Turkey. Some characters are found important to distinguish the species within the genera. The investigated species can be divided as mesophyll type: bifacial (H. niger L., H. albus L. ) and equifacial (H. aureus L., H. pusillus L., H. reticulatus L.). Druse crystals are recorded only in mesophyll of $H$. albus. Stomata present on both surfaces, are anisocytic (usually) and anomocytic types. H. reticulatus can be distinguished from other species considering types of trichomes in the stem. Vascular bundles are bicollateral types.
\end{abstract}

\section{Introduction}

The cosmopolitan Solanaceae family includes 102 genera with 2460 species in the world. In Turkey, there are 12 genera and 36 species of the Solanaceae and most of them are wild herbs (Erik and Tarıkahya 2004; Selvi et al. 2009). The plants of this family are well known as a natural source of tropan alkaloids including hyoscyamine, scopolamine and atropine (Kartle et al. 2003) and are cultivated for their medicinal importance (Etminan et al. 2012). The genus Hyoscyamus occupies the phyto-geographical region of Sino-Japanese. Hyoscyamus a small herbaceous genus having 26 species all over the world (Yousaf et al. 2008) and is represented by 6 species in Turkey (Baytop 1978; Güner et al. 2000; Güner 2012). Hyoscyamus species have medicinal importance because of their hyoscyamine and scopolamine content (Mateus et al. 1998, 2000). Therefore, it is widely used as sedative and painless in folk medicine (Baytop 1999). Although the chemical aspects of Hyoscyamus have already been investigated, anatomical information is scarce for the species of the genera. There are systematic studies on Hyoscyamus taxa (Ghahreman et al. 1999, Sheidai et al. 2000). Anatomical studies carried on Hyoscyamus species have been shown to be insufficient and limited to a few taxa such as H. reticulatus (Baytop 1971, Ghassemi et al. 1995).

The present study describes the stem and leaf structure of five Hyoscyamus species growing in Turkey with the purpose of pointing out anatomical characters useful to distinguish these species.

\section{Materials and Methods}

Materials used in this study were collected from plants in their natural habitat. Voucher specimens were kept in the Harran University, Department of Biology, Şanlıurfa and are listed in Table 1. Fresh materials were fixed in 70\% alcohol. Developed middle cauline leaves from fully

\footnotetext{
"Author for correspondence: <eyuperdogan77@gmail.com>. ${ }_{-}^{1}$ Harran University, Faculty of Science \& Art, Department of Biology, Yenişehir Campus, 63300 Şanlıurfa, Turkey. ${ }^{2}$ Giresun University, Espiye Vocational School, Department of Plant and Animal Production, Programme of Medicinal and Aromatic Plants, Espiye, Giresun 28600, Turkey. ${ }^{3}$ Balıkesir University, Altınoluk Vocational School, Department of Plant and Animal Production Programme of Medicinal and Aromatic Plants, Edremit, Balıkesir 10870, Turkey.
} 
flowered plants were used in anatomical study. Five samples were taken from each specimen and free hand sectroning of stem and leaves were made for anatomical studies. Tissues were stained with phloroglusine $+\mathrm{HCl}$ and embedded in glycerine jelly. In addition, chlorophyll in leaves were cleared with chloral hydrate (Yakar-Tan 1982). Anatomical sections were examined by Olympus BX50 phase contrast binocular microscope and microphotographs of sections were taken by Ucmo SO5100 KPA digital camera attachment.

\section{Results and Discussion}

The transverse section of the stem presented in Fig. 1. The epidermis consists of a single layer of isodiametric cells. Covering hairs consist of stalked glandular types in a stem. The stalked glandular hairs have usually elongated 2-3-celled stalk, and with pear-shaped unicellular head. They are recorded only with pear-shaped multicellular head in H. reticulatus (Fig. 1c). The collenchyma tissue is located immediately under the epidermis in some species (Fig. 1). It is also
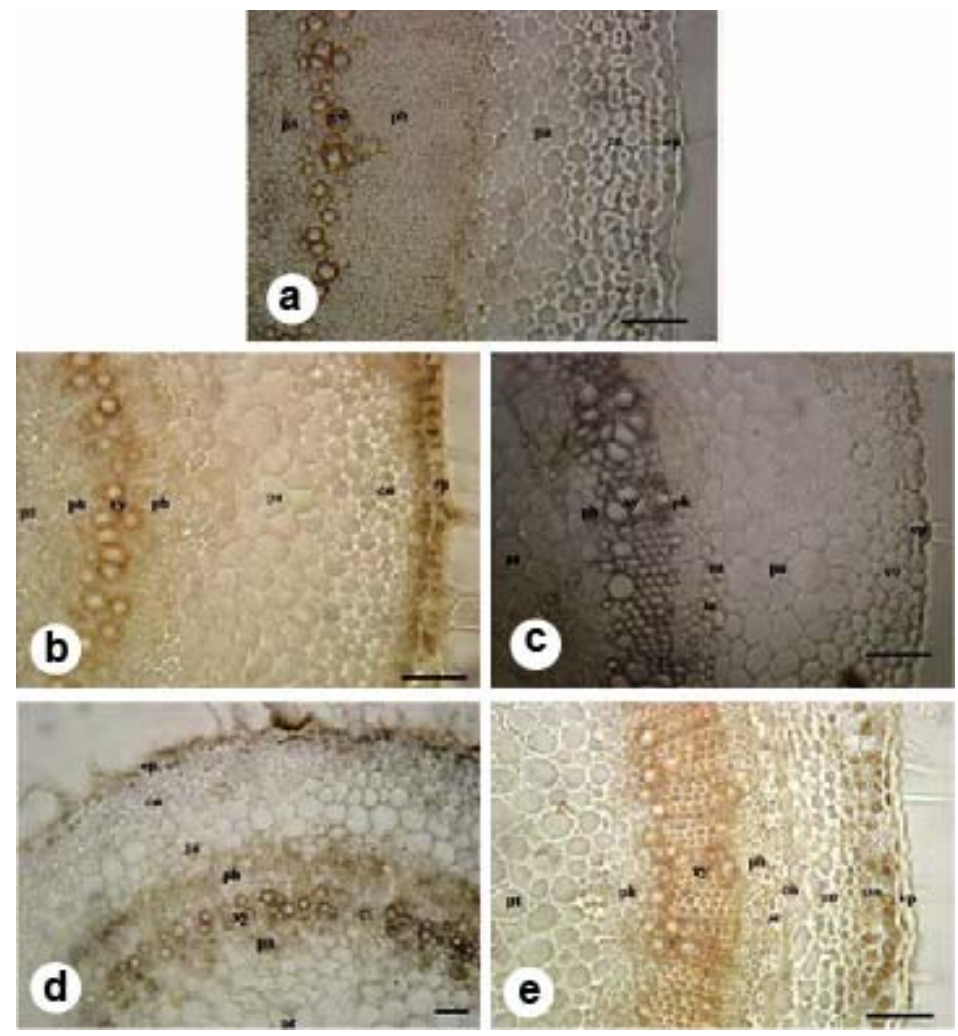

Fig. 1. Comparative stem structures of Hyoscyamus species. a. H. pusillus, b. H. niger, c. H. reticulatus, d. H. albus, e. H. aureus. eh: eglandular hair, ep:. epidermis, co: collenchyma, pa: parenchyma, sc: sclerenchyma, en: endodermis, ph: phloem, xy: xylem, pt: pith parenchyma (Scale bar: $100 \mu \mathrm{m})$.

located under the parenchyma in some species (Fig. 1). The collenchyma is absent in some species. Parenchyma tissue, which is 2-7-layered, is composed of usually round and ovoid or polyhedral cells. The endodermis consists of irregularly rectangular cells, or it is not distinguishable in some species. Pericycle is sclerenchymatic or parenchymatic and 1-3-layered or 
not distinguishable. The vascular bundle type is bicollateral. The cambium is not distinguishable. Phloem is located on both sides of the xylem. The xylem comprises trachea and tracheids. The trachea are orbicular or ovoid while the tracheids are polyhedral. The rays are usually uniseriate, rarely biseriate. The pith consists of large round or polyhedral parenchymatic cells.

At cross-section it is observed that the epidermis consists of a single layer of cells which are isodiametric. Stomata present on both surfaces, are anisocytic (usually) and anomocytic types (Fig. 3 c,d). The both surfaces of leaves have stalked glandular trichomes The density of the stalked glandular hairs varies in Hyoscyamus leaves (Fig. 3e-g.). The stalked glandular hairs have usually elongated 3-celled stalk, rarely bicellular, and with pear-shaped unicellular head. They are recorded only with a pear-shaped multicellular head and elongated 2-3-celled stalk in $H$. reticulatus. The investigated species can be divided as mesophyll type: bifacial $(H$. niger, $H$. albus) (Fig. 2 b,d) and equifacial (H. aureus, H. pusillus, H. reticulatus) (Fig. 2a,c,e). There are some differences in the number of the mesophyll cells. Druse crystals are recorded only in mesophyll of H. albus (Fig. 2 d). The vascular bundle is bicollateral type. In the midrib region, there are collenchymatous tissue under the upper and lower side of vein (Fig. 3a,b).
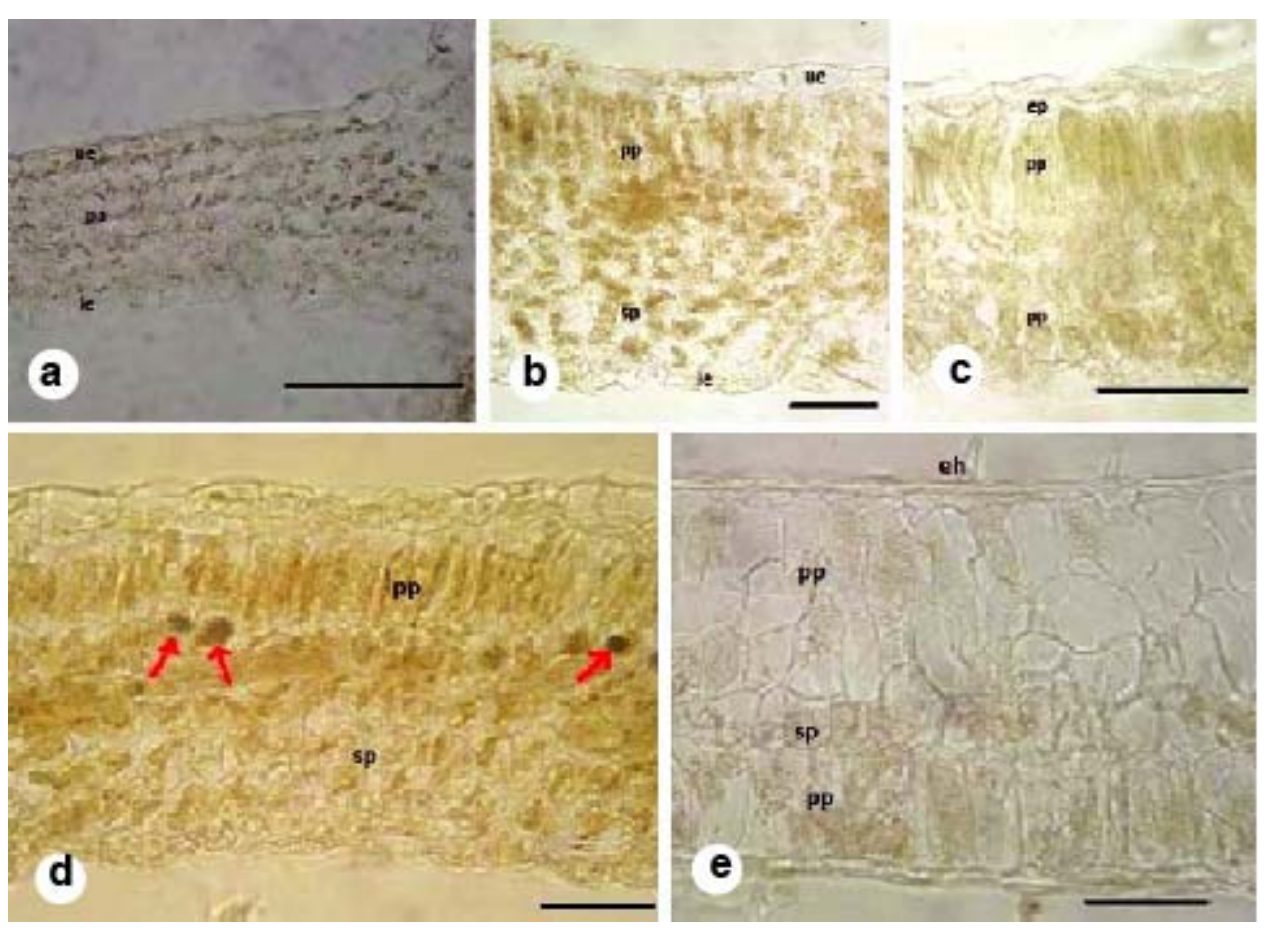

Fig. 2. Comparative mesophyll tissue of Hyoscyamus species. a. H. pusillus, b. H. niger, c. H. reticulatus, d. H. albus, e. H. aureus. eh: eglandular hair, gh: glandular hair, ue. upper epidermis, pa: parenchyma, pp: palisade parenchyma, sp: spongy parenchyma, le: lower epidermis. Druse crystals are shown by arrows. (Scale bar: $100 \mu \mathrm{m}$ ).

The trichomes of Hyoscyamus show differences among the species studied as in the case of Solanum (Seith 1979,Seith and Sullivan 1990). The trichomes found in the Iranian Hyoscyamus species are divided into two hair classes; The first is unbranched hairs, with or without glandular type while second class is branched to dentritic hairs, with or without glandular type. Type of trichomes can be successfully used for the delimitation of the subgenera and species (Ghahreman 
et al. 1999). The trichomes in the stem and leaves may be divided into two categories: I. Head multicellular, stalk 2-3-celled, II. Head unicellular, stalk 2-3-celled. The stalked glandular hairs have usually elongated 3-celled stalk, rarely bicellular, and with pear-shaped unicellular head (Fig. 4). They are recorded only with pear-shaped multicellular heads in trichomes of $H$. reticulatus (Fig. 3f). The cortex consists of only parenchymatic cells in $H$. pusillus (Fig. 2a.). The collenchyma tissue is located immediately under the epidermis in $H$. niger and $H$. reticulatus, followed by parenchyma (Fig. 2). Also, the collenchyma is located under the parenchyma in $H$. aureus (Fig. 1e). A single layer parenchyma tissue is located immediately under

Table 1. Collection data and collectors's number of studied Hyoscyamus L. species.

\begin{tabular}{|c|c|c|c|c|c|}
\hline Taxa & \multicolumn{5}{|c|}{ Collection data } \\
\hline H. pusillus L. & \multicolumn{5}{|c|}{$\begin{array}{l}\text { B7 Tunceli: } 2 \mathrm{~km} \text { north of Pertek port, crevices and fissures on rock faces. } 13.06 .2004,1200 \mathrm{~m} \text {, } \\
\text { Aslan 1529. B8 Elazlğ: Harput Castle, Stony or rocky places, waste places, roadsides, } 15.05 .2004 \text {, } \\
1400 \mathrm{~m} \text {. Aslan } 1539 \text {. C5 Niğde: } 2 \mathrm{~km} \text { north of Niğde, roadside verge, dumping ground, } \\
25.05 .2003,1000 \mathrm{~m} \text {. Aslan } 1451 \text {. }\end{array}$} \\
\hline H. niger $\mathrm{L}$. & \multicolumn{5}{|c|}{$\begin{array}{l}\text { B8 Batman: in downtown of Hasankeyf, on the castle wall, } 19.05 .2004,800 \mathrm{~m} \text {., Aslan } 1448 \text {. C6 } \\
\text { Kahramanmarass: } 10 \mathrm{~km} \text { south of Kahramanmaraş, the margins of arable fields, } 14.05 .2004,550 \\
\text { m., Aslan 1534. C8 Mardin: Waste places, roadsides, 19.05.2004, } 1350 \mathrm{~m} \text {., Aslan } 1536 \text {. }\end{array}$} \\
\hline H. reticulatus $\mathrm{L}$. & \multicolumn{5}{|c|}{$\begin{array}{l}\text { B8 Diyarbakır: Ergani, Sölen village, Steppe, Stony or rocky places, waste places, } 14.05 .2004 \\
1100 \text { m, Aslan 1521. C5 Niğde: North of Ulukışla, along forest margins, open habitats } \\
20.06 .2003,1100 \text { m., aslan } 1399 \text {., C7 Şanlıurfa: Küçüksergen village, stony steppe, 19.06.2003 } \\
550 \text { m., Aslan } 1411 \text {. }\end{array}$} \\
\hline H. albus $\mathrm{L}$. & \multicolumn{5}{|c|}{$\begin{array}{l}\text { C6 Gaziantep: Antep castle, rock crevices on the wall, } 31.07 .2003,650 \mathrm{~m} . \text {., Aslan 1352, C7 } \\
\text { Sanliurfa: Urfa Castle, Stony or rocky places, Foot of rocks and walls, } 11.04 .2004,600 \mathrm{~m} \text {., Aslan } \\
1501 . \text { C8 Mardin: Mardin castle, in fissures on limestone, } 13.05 .2004,1300 \mathrm{~m} . \text {., Aslan } 1528 \text {, }\end{array}$} \\
\hline H. aureus $\mathrm{L}$. & \multicolumn{5}{|c|}{$\begin{array}{l}\text { C6 Gaziantep: Nizip, Rum castle, crevices and fissures on rock, } 04.04 .2003,550 \mathrm{~m} \text {, Aslan } 1254 \text {. } \\
\text { C7 Şanlıurfa: Birecik castle, crevices and fissures on rock, } 24.05 .2003,650 \mathrm{~m} \text {., Aslan 1356, C8 } \\
\text { Mardin: Castle, Rock crevices, old walls, } 14.05 .2004,1250 \mathrm{~m} \text {, Aslan } 1525 \text {. }\end{array}$} \\
\hline \multirow{2}{*}{ Characters } & \multicolumn{5}{|c|}{ Investigated taxa } \\
\hline & H. pusillus & H. niger & H. reticulatus & H. albus & H. aureus \\
\hline \multicolumn{6}{|c|}{ Stem } \\
\hline $\begin{array}{l}\text { Stalked } \\
\text { glandular hair }\end{array}$ & $\begin{array}{l}\text { Unicellular head 2- } \\
\text { 3-(-6) celled stalk }\end{array}$ & $\begin{array}{l}\text { Unicellular head } \\
1-6-(-8) \text { celled } \\
\text { stalk }\end{array}$ & $\begin{array}{l}\text { Multicellular head } \\
\text { 2-3- celled stalk }\end{array}$ & $\begin{array}{l}\text { Unicellular head } \\
\text { 2-4-(-8) celled } \\
\text { stalk }\end{array}$ & $\begin{array}{l}\text { Unicellular head } \\
2-3 \text { - celled stalk }\end{array}$ \\
\hline Collenchyma & - & $4-6$ & $4-6$ & $3-5$ & $2-3$ \\
\hline Parenchyma & $5-7$ & $2-4$ & $3-6$ & $4-6$ & $2-4$ \\
\hline Endodermis & Rectangular & Distinguishable & Distinguishable & Distinguishable & Rectangular \\
\hline Pericycle & 1-2 sclerenchymatic & 1-3 parenchymatic & 1-3 parenchymatic & $\begin{array}{l}1-3 \text { paren- } \\
\text { chymatic }\end{array}$ & $\begin{array}{l}1-3 \\
\text { sclerenchymatic }\end{array}$ \\
\hline Pith cells & Polyhedral & Polyhedral & $\begin{array}{l}\text { round } \\
\text { aves }\end{array}$ & Polyhedral & Polyhedral \\
\hline $\begin{array}{l}\text { Stalked } \\
\text { glandular hair }\end{array}$ & $\begin{array}{l}\text { Unicellular head 2- } \\
3-(-6) \text { celled stalk }\end{array}$ & $\begin{array}{l}\text { Unicellular head } \\
\text { 3-4-(-6) celled } \\
\text { stalk }\end{array}$ & $\begin{array}{l}\text { Multicellular head } \\
\text { 2-3- celled stalk }\end{array}$ & $\begin{array}{l}\text { Unicellular head } \\
3-4-(-6) \text { celled } \\
\text { stalk }\end{array}$ & $\begin{array}{l}\text { Unicellular head } \\
\text { 2-3- celled stalk }\end{array}$ \\
\hline $\begin{array}{l}\text { Mesophyll type } \\
\text { Druse crystals }\end{array}$ & $\begin{array}{l}\text { Equifacial } \\
\text { Abscent }\end{array}$ & $\begin{array}{l}\text { Dorsiventral } \\
\text { Abscent }\end{array}$ & $\begin{array}{l}\text { Equifacial } \\
\text { Abscent }\end{array}$ & $\begin{array}{l}\text { Dorsiventral } \\
\text { Present }\end{array}$ & $\begin{array}{l}\text { Equifacial } \\
\text { Abscent }\end{array}$ \\
\hline
\end{tabular}

the epidermis, followed by collenchyma and parenchyma in H. niger and H. reticulatus. Pericycle is 1-3-layered and sclerenchymatic in $H$. pusillus, $H$. aureus. It is parenchymatic in $H$. niger, $H$. reticulatus and $H$. albus (Table 2). Stomata are present on both leaf surfaces (amphistomatic leaves), which are anisocytic (usually) and anomocytic types in studied species (Fahn 1990; 
Yentür 2003). According to Metcalfe and Chalk (1950), amphistomatic leaves are common in Solanaceae, although Cosa de Gastiazoro (1994) described hypostomatic leaves in some species of the family. The investigated species can be divided as mesophyll type: bifacial $(H$. niger, H. albus) and equifacial (H. aureus, H. pusillus, H. reticulatus). Bifacial mesophyll is the most
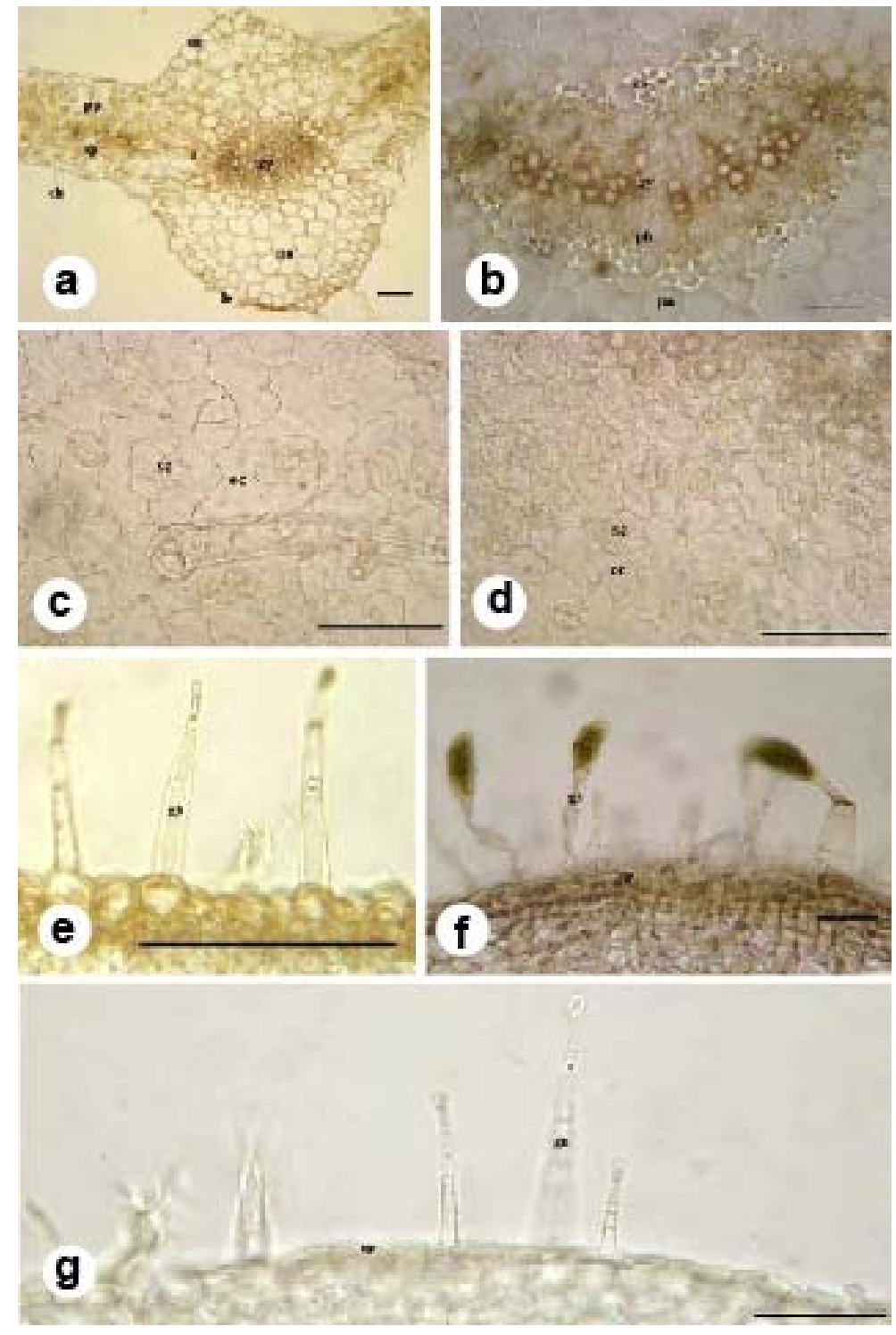

Fig. 3. General anatomical structures of Hyoscyamus species. a-b. Middle vascular tissue observed on Hyoscyamus leaves ( a. Leaf middle region $(H$. albus), b. Leaf middle vascular bundle $(H$. niger); c-d Stoma types observed Hyoscyamus species (c. Anisocytic stomata (H. aureus); d. Anomocytic stomata; (H. reticulatus); e-g. Trichomes observed in Hyoscyamus species (e. H. albus, f. H. reticulatus, g. H. pusillus). (Scale bar: $100 \mu \mathrm{m})$. 
frequent in Solanaceae, but equifacial mesophyll for some species of the family is also reported (Cosa de Gastiazoro 1994). Shape, structure and distribution of druse crystals are important from the taxonomic point of view (Metcalfe and Chalk 1950, Fahn 1990). These are recorded only in mesophyll of H. albus in our studies. Druse crystals, as described for some species of Solanaceae (Ogundipe 1992), were observed in the mesophyll of Calibrachoa sellowiana and C. caesia. Baytop (1971) has found high number of druse crystals in the leaf mesophyll during the anatomical study of $H$. leptocalyx, and the similar high density druse crystals in the leaf mesophyll. The reports of Ghassemi (1995) on the leaf anatomy of $H$. reticulatus are similar in general, except the mesophyll layer, while he has observed a dorsiventral layer, we have seen an equifacial layer (Fig. 2-c). In a phylo-genetical study of Iranian species of Hyoscyamus, Sheidai et al. (2000) reported that $H$. niger is closely related to $H$. reticulatus. The present investigation has shown that these two species are anatomically similar.

As a result of anatomical studies carried on Hyoscyamus taxa; presence or absence of druse crystals, as well as their shape, structure and distribution, the presence of trichome on stem and leaf, number of collenchyma and parenchyma layer, sclerenchymatic or parenchymatic of pericycle, mesophyll structure, and stomata types (anisocytic and anomocytic) were found to be important characters for identification of Hyoscyamus species.

\section{References}

Baytop A 1971. Hyoscyamus leptocalyx üzerinde botanik araştırması. J. Fac. Pharm. Istanbul. 7: 138-146.

Baytop A 1978. Hyoscyamus L. In: Flora of Turkey and the East Aegean Islands, Vol. VI, Davis PH, (Ed.), Edinburgh University Press, Edinburgh. pp. 453-456.

Baytop T 1999. Türkiye'de Bitkilerle Tedavi. Nobel Tıp Kitapevi, İstanbul. pp. 164-165.

Cosa de Gastiazoro MT 1994. Estudio morfoanatomico de organos vegetativos em Cestroideae (Solanaceae), III: Tribu Schwenckieae. Kurtziana 23: 9-25.

Erik S and Tarıkahya B 2004. Türkiye Florası Üzerine. Kebikeç 17: 139-163.

Etminan A, Omidi M, Hervan EM, Naghavi MR, Zadeh SR and Pirseyedi M 2012. The study of genetic diversity in some Iranian accessions of Hyoscyamus sp. using amplified fragment length polymorphism (AFLP) and retrotransposon/AFLP markers. African J. Biotech. 11(43): 10070-10078.

Fahn A 1990. Plant Anatomy. 4th ed. Butterworth. Heinemann Pub. Ltd., Jerusalem, Israel.

Ghahreman A, Khatamsaz M. and Ganj-Karimi M 1999. Leaf epidermal studies in the genus Hyoscyamus L. (Solanaceae) in Iran. The Iranian Bot. 8(1): 81-90.

Ghassemi N, Sajjadi S. and Saghai F 1995. A study on the morphology and phytochemistry of Hyoscyamus reticulatus L. DARU Pharm. Sci. 5(1-2): 1-10.

Güner A, Özhatay N, Ekim T. and Başer KHC (Eds) 2000. Flora of Turkey and the East Aegean Islands, Vol. 11: Edinburgh University Press, Edinburgh. 576-577.

Güner A, 2012. Hyoscyamus L.: Güner, A., Aslan, S., Ekim, T., Vural, M. \& Babaç, M.T. (edlr.). Türkiye Bitkileri Listesi (Damarlı Bitkiler). Nezahat Gökyiğit Botanik Bahçesi ve Flora Araştırmaları Derneği Yayını. İstanbul.

Kartle M, Kurucu S. and Altun L 2003. Quantitative analysis of 1-Hyoscyamine in Hyoscyamus reticulatus L. by GC-MS. Turk. J. Chem. 27: 565-569.

Mateus L, Cherkaoui S, Christen P and Veuthey JL 1998. Capillary electrophoresis for the analysis of tropane alkaloids: pharmaceutical and phytochemical applications. Pharm. and Biomed. 18: 815-825.

Mateus L, Cherkaoui S, Christen P and Oksman-Caldentey KM 2000. Simultaneous determination of scopolamine, hyoscyamine and littorine in plants and diferent hairy root clones of Hyoscyamus muticus by micellar electrokinetic chromatography. Phytochem. 54:517-523.

Metcalfe CR and Chalk L 1950. Anatomy of The Dicotyledons (Leaves,stem and wood in relation to taxonomy with notes on economic uses), Vol. 2. Oxford University Press, Clarendon press, London. 
Ogundipe OT 1992. Leaf epidermal studies in the genus Datura Linn. (Solanaceae). Phytomorphology 42 : 209-217.

Rechinger KH 1972. Flora Iranica. Flora Des Iranischen Hochlandes Und Der Umrahmenden Gebirge. Persien, Afghanistan, Teile Von West- Pakistan, Nord-Iraq, Azerbaidzhan, Turkmenistan. pp. 573.

Sethe A 1979. Hair types as taxonomic characters in Solanum. In: The Biology and Taxonomy of the Solanaceae. Hawkes JG, Lester RN and Skelding AD (eds). pp. 307-319.

Seithe A and Sulivan RJ 1990. Hair morphology ad systematic in Physalis (Solanaceae). Plant Syst. Evol. 170: 193-204.

Selvi S, Aslan M and Erdoğan E 2009. Anatomical studies on endemic Lycium anatolicum A. Baytop et R. Mill (Solanaceae) vegetative organs, distributed in Turkey. J. App. Biol. Sci. 3(1): 29-33.

Sheidai M, Khatamnaz M and Mosallanejad M 2000. Numerical Taxonomy and seed protein analysis of Hyoscyamus species in Iran. J. Sci. I. R. Iran 11(2):83-91.

Yakar-Tan N 1982. Bitki Mikroskopisi Klavuz Kitabı. Istanbul Üniv. Fen Fak. Yay. No: 166, Istanbul.

Yentür S 2003. Bitki Anatomisi. İstanbul Üniversitesi Fen Fakültesi Yayınları, No: 227, Istanbul.

Yousaf Z, Masood S, Shinwari ZK, Khan MA and Rabani A 2008. Evaluation of taxonomic status of medicinal species of the genus Hyoscyamus, Withania, Atropa and Datura based on polyacrylamide gelelectrophoresis. Pak. J. Bot. 40(6): 2289-2297.

(Manuscript received on 11 Setember, 2013; revised on 26 February, 2014) 